\title{
Nonhematic Cells to Leukocytes Ratio Measurement
}

National Cancer Institute

\section{Source}

National Cancer Institute. Nonhematic Cells to Leukocytes Ratio Measurement. NCI

Thesaurus. Code C147402.

The determination of the ratio of nonhematic cells compared to leukocytes present in a sample. The measurement may be expressed as a ratio or percentage. 